\title{
Evaluation of the biomethane potential of solid fish waste
}

\author{
M. Eiroa ${ }^{\mathrm{a}, \mathrm{b}}$, J.C. Costa ${ }^{\mathrm{b}}$, M.M. Alves ${ }^{\mathrm{b}}$, C. Kennes ${ }^{\mathrm{a}}$, M.C. Veiga ${ }^{\mathrm{a}, *}$ \\ ${ }^{a}$ Chemical Engineering Laboratory, Faculty of Sciences, University of A Coruña, Rúa da Fraga $n^{\circ}$. 10, 15008 A Coruña, Spain \\ ${ }^{\mathrm{b}}$ IBB - Institute for Biotechnology and Bioengineering, Centre of Biological Engineering, University of Minho, 4710-057 Braga, Portugal
}

\section{A R T I C L E I N F O}

Article history:

Received 30 May 2011

Accepted 21 March 2012

Available online 18 April 2012

\section{Keywords:}

Anaerobic digestion

Biochemical methane potential

Fish waste

Gorse

Waste/inoculum ratio

\begin{abstract}
A B S T R A C T
Manufacturing processes in fish canning industries generate a considerable amount of solid waste that can be digested anaerobically. The aim of this research was to study the biochemical methane potential of different solid fish waste. For tuna, sardine and needle fish waste, around $0.47 \mathrm{~g} \mathrm{COD}-\mathrm{CH}_{4} / \mathrm{g} \mathrm{COD}$ added was obtained in batch experiments with $1 \% \mathrm{TS}$; whereas for mackerel waste, the methane production

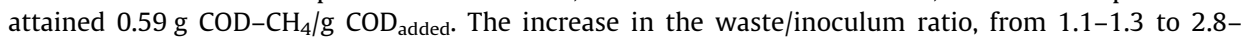

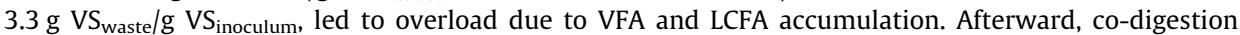
assays of fish waste with gorse were undertaken but the biochemical methane potential did not improve. (c) 2012 Elsevier Ltd. All rights reserved.
\end{abstract}

\section{Introduction}

The fish canning industries are an important sector in Galicia (NW of Spain), representing most of the total Spanish production. Galician cannery industries manufacture a high variety of raw materials. Tuna and bonito processing account for more than half of the total production; sardine processing also involves an important percentage and other species are processed in a minor quantity. The main steps in the tuna manufacturing process are defrosting, peeling, cooking, canning and finally, the finishing steps (sauce filling, washing of cans, sterilization, etc.). Sardine processing includes scraping, cutting, conveying, canning, cooking and the finishing steps. The amount of solid waste generated in fish canning industries is important. During the manufacturing processes of species, the amount of raw products converted into waste can reach up to $50 \%$ by weight (data provided by Xunta de Galicia).

Anaerobic digestion has a strong potential for treating biodegradable solid waste. It is considered as an organic recycling technology, as it produces renewable energy from combustion of the biogas obtained. This could replace fossil fuel-derived energy and reduce environmental impacts including global warming and acid rain. On the other hand, the anaerobic digestion of organic waste produces a digestate, which can be used in agriculture after a stabilization or composting step. Anaerobic digestion of organic solid waste is an established technology in Europe, with 200 full-scale plants treating almost 6 million tons per year (De Baere and Mattheeuws, 2010). The process is very complex and it is catalyzed by

\footnotetext{
* Corresponding author. Tel.: +34981 167000; fax: +34 981167065.

E-mail address: veiga@udc.es (M.C. Veiga).
}

a consortium of microorganisms that in a joint action convert complex macromolecules into low molecular weight compounds such as methane, carbon dioxide, water and ammonia.

The biochemical methane potential is a key parameter for assessing design, economic and managing issues for the full-scale implementation of the anaerobic digestion process. This parameter depends on the solid waste composition. A wide variety of substances, present in high concentrations in waste, can cause inhibition or failure of anaerobic digestion. An interesting option for improving the yield of anaerobic digestion of solid waste is codigestion. That is the use of a co-substrate that in most cases improves biogas production due to positive synergism established in the digestion medium and to the supply of missing nutrients (Mata-Alvarez et al., 2000).

Literature on methane production from fish waste is scarce. Mshandete et al. (2004) tested the batch anaerobic digestion of fish waste obtained from the landing beach. The ratio of waste/inoculum was found to be a critical parameter since the methane yield increased significantly when the waste/inoculum ratio decreased from 1.6 to $0.05 \mathrm{~g} \mathrm{VS}_{\text {waste }} / \mathrm{g} \mathrm{VS}_{\text {inoculum. The highest methane yield from fish }}$ waste was $0.39 \mathrm{~L} \mathrm{CH}_{4} / \mathrm{g} \mathrm{VS}_{\text {added }}$ at $0.05 \mathrm{~g} \mathrm{VS}_{\text {waste }} / \mathrm{g} \mathrm{VS}_{\text {inoculum }}$ and $5 \% \mathrm{TS}$ of waste. Other authors used fish waste in co-digestion in order to improve methane production of other waste. Callaghan et al. (1999) tried to increase the batch biomethane production of cattle slurry through co-digestion with fish offal obtained from a rainbow trout farm. The co-digestion mixture was 70\% (w/w) cattle slurry, $20 \%$ fish offal and $10 \%$ digester inoculum. The methane yield was enhanced from $0.28 \mathrm{LCH}_{4} / \mathrm{g} \mathrm{VS}_{\text {removed }}$ obtained with cattle slurry alone to $0.38 \mathrm{~L} \mathrm{CH}_{4} / \mathrm{g} \mathrm{VS}_{\text {removed }}$ obtained with the mixture. Bouallagui et al. (2009) also studied the improvement of fruit and vegetable waste 
digestion with fish waste addition. The fish waste was collected from a market and the assays were undertaken in an anaerobic sequencing batch reactor. The reactor was operated at an organic loading rate of $2.5 \mathrm{~g} \mathrm{VS} / \mathrm{L} . \mathrm{d}$, of which approximately $90 \%$ were from fruit and vegetable waste, and a hydraulic retention time of $10 \mathrm{~d}$. The addition of fish waste slightly increased the gas production yield (8.1\%) compared to anaerobic digestion of fruit and vegetable waste alone.

In this study, the co-digestion with gorse was selected since gorse is very abundant in Galicia (Northwest Spain). Land surface taken up in Galicia by bush species is around one million hectares and it is increasing as a consequence of the abandonment of agricultural land that is rapidly becoming scrubland. The shrubs constitute one of the main sources of forest fires and it is important to avoid their accumulation (Núñez-Regueira et al., 2002).

The aim of this research was to study the biochemical methane potential of solid fish waste. Anaerobic batch assays were performed with tuna, sardine, mackerel and needle fish waste. The influence of the quality and quantity of inoculum was also studied. Afterward, co-digestion assays of fish waste with gorse were undertaken in order to try to improve methane production.

\section{Materials and methods}

\subsection{Solid waste and inoculum}

Solid fish waste was obtained from a canning industry in Galicia (Northwest Spain); the waste came from tuna, sardine, mackerel and needle fish. The tuna waste consisted of heads, tails, fish bones and viscera; while the sardine, mackerel and needle waste contained mainly heads and viscera. After collection, the fish waste was dried and ground to $3-5 \mathrm{~mm}$ particle size using an electronic kitchen blender. The ground sample of each fish species was characterized and individually used for biomethane potential determination. The gorse species was Ulex europaeus, the most abundant and the only species native of Western Europe. After harvest, the gorse was also ground to $1-3 \mathrm{~mm}$ particle size. The ground gorse was characterized and used in co-digestion assays with fish.

Two different anaerobic inocula were used; the first one was the suspended sludge obtained from an urban wastewater treatment plant. The solid concentration was $13 \mathrm{~g} \mathrm{VS} / \mathrm{L}$ with a VS/TS ratio of 0.71 . The specific acetoclastic activity (SAA) of the inoculum was determined using acetate $(30 \mathrm{mM})$ and the specific hydrogenotrophic methanogenic activity (SHMA) using a mixture of $\mathrm{H}_{2} / \mathrm{CO}_{2}$ (80:20 v/v, at 1 bar) as substrates. The SAA was found to be less than $10 \mathrm{~mL} \mathrm{CH}_{4} / \mathrm{g}$ VS.d and the SHMA was $695 \mathrm{~mL} \mathrm{CH}_{4} / \mathrm{g}$ VS.d. The second inoculum was the granular sludge collected from a brewery industry. The solid concentration was $34 \mathrm{~g} \mathrm{VS} / \mathrm{L}$ with a VS/TS ratio of 0.93.The specific methanogenic activities were 55 and $655 \mathrm{~mL} \mathrm{CH}_{4} / \mathrm{g}$ VS.d for the SAA and SHMA, respectively.

\subsection{Methane production assays}

The biodegradability assays were performed in glass flasks closed with butyl rubber stoppers which were sealed with aluminum crimps (Angelidaki et al., 2009). All assays were undertaken in triplicate and bicarbonate $(5 \mathrm{~g} / \mathrm{L}$ ) was added to give suitable alkalinity. After adding the medium, the ground waste and the inoculum, the headspace was flushed with $\mathrm{N}_{2} / \mathrm{CO}_{2}(80 / 20, \mathrm{v} / \mathrm{v})$ and $\mathrm{Na}_{2} \mathrm{~S}$ was added as reducing agent $(1 \mathrm{mM})$. The vials were then incubated at $37^{\circ} \mathrm{C}$ and the pressure increase was monitored using a hand held pressure transducer. At regular time intervals, the methane content of biogas was analyzed and the volume of methane produced was corrected for standard temperature and pressure conditions. The methane production due to biomass decay and the presence of possible residual substrates was subtracted by performing blank controls. The methane production was defined as the maximum plateau achieved in methane production curves after correction due to the residual substrate present in the inoculum divided by the amount of waste initially added.

First, digestion assays with fish waste were carried out using suspended sludge as inoculum. For each fish waste, three total solid concentrations were tested: $1,2.5$ and $5 \% \mathrm{TS}\left(\mathrm{w}_{\text {waste }} / \mathrm{v}\right)$; the waste/inoculum ratios ranged between 1.1-1.3, 2.8-3.3 and 5.7$6.5 \mathrm{~g} \mathrm{VS}_{\text {waste }} / \mathrm{g} \mathrm{VS}_{\text {inoculum, }}$, respectively. Then, aiming at accelerating the anaerobic digestion process and assessing the effect of the inoculum/waste ratio, mackerel was used and digested with different quantities of anaerobic granular sludge. The mackerel concentration was $2.5 \% \mathrm{TS}\left(\mathrm{w}_{\text {waste }} / \mathrm{v}\right)$ and the studied waste/inoculum ratios were $0.8,1.3$ and $2.5 \mathrm{~g} \mathrm{VS}_{\text {waste }} / \mathrm{g} \mathrm{VS}_{\text {inoculum. }}$ Afterward, codigestion assays of tuna waste with gorse were performed using granular sludge. Different tuna:gorse ratios were tested: 100:0, $80: 20,60: 40,50: 50$ and 0:100. The total solid concentration was maintained at $2.5 \% \mathrm{TS}\left(\mathrm{w}_{\text {waste }} / \mathrm{v}\right)$ and the waste/inoculum ratios ranged between 1.2 and $1.4 \mathrm{~g} \mathrm{VS}_{\text {waste }} / \mathrm{g} \mathrm{VS}_{\text {inoculum. }}$.

\subsection{Analytical methods}

\subsubsection{Solid samples}

Total and volatile solids (TS and VS) and total Kjeldahl nitrogen (TKN) were measured according to Standard Methods (APHA et al., 1998). The chemical oxygen demand (COD) was determined using standard kits (Hach Lange, Düsseldorf, Germany). The used kits had a range of concentrations from 5 to $60 \mathrm{~g} \mathrm{COD/L}$. The amount of added waste was around $5 \mathrm{mg}$. The COD of each sample was measured five times, the standard deviation always being below $5 \%$. The total fat content was extracted with diethyl ether in a Soxtec System. The oily waste was added to thimbles previously weighted and placed in the apparatus. The temperature of the circulating heating fluid was $90^{\circ} \mathrm{C}$. After extraction, the samples were dried and the weight was recorded.

\subsubsection{Liquid samples}

Ammonia was determined according to Standard Methods (APHA et al., 1998). Volatile fatty acids (VFA) were determined by high performance liquid chromatography using a Metacarb column maintained at $60^{\circ} \mathrm{C}$ and with UV/VIS detection at $210 \mathrm{~nm}$. The mobile phase was sulfuric acid $(5 \mathrm{mM})$ fed at a rate of $0.6 \mathrm{~mL} / \mathrm{min}$. Crotonic acid was used as internal standard. Long chain fatty acids (LCFA) (lauric C12:0, myristic C14:0, palmitic C16:0, palmitoleic C16:1, stearic C18:0 and oleic C18:1 acids) analyses were done as described in Neves et al. (2009). The LCFA were analyzed in the liquid and solid matrix since they were adsorbed/ accumulated onto the solid matrix. Free fatty acids present in the samples were esterified with $\mathrm{HCl}$ :1-propanol and extracted with dichloromethane. Quantification was done with a gas chromatograph equipped with a flame ionization detector. LCFA were separated using a CP-Sil $52 \mathrm{CB}$ column with helium as the carrier gas fed at a rate of $1 \mathrm{~mL} / \mathrm{min}$. Temperatures of the injector and detector were 220 and $250^{\circ} \mathrm{C}$, respectively. The initial oven temperature was $50^{\circ} \mathrm{C}$, maintained for $2 \mathrm{~min}$, followed by a $10^{\circ} \mathrm{C} / \mathrm{min}$ ramp up to $225^{\circ} \mathrm{C}$ and finally isothermal conditions were maintained for $10 \mathrm{~min}$.

\subsubsection{Gas samples}

The methane content of biogas was analyzed with a gas chromatograph, equipped with a flame ionization detector and a Chromosorb 101 column. Nitrogen was used as carrier gas, at a flow rate of $30 \mathrm{~mL} / \mathrm{min}$. Temperatures of the injector, oven and detector were 110,35 and $220^{\circ} \mathrm{C}$, respectively. 


\section{Results and discussion}

Moisture content, volatile solids and nitrogen content were similar for all fish waste (Table 1). The organic matter and the total fat content significantly varied for the different fish waste. The organic fraction of the dry waste was high, between 74 and 85\%; therefore, the fish waste is a good candidate for anaerobic digestion because they contain high levels of potentially biodegradable materials.

\subsection{Digestion of solid fish waste}

Results of cumulative methane production in the assays with different fish waste are presented in Fig. 1. For all fish waste, the methane production was higher at $1 \% \mathrm{TS}$ and decreased when the total solids increased, indicating inhibition by substrate concentration. For the three total solid concentrations, the waste/inoculum ratios increased from 1.1-1.3 to 5.7-6.5 $\mathrm{g} \mathrm{VS}_{\text {waste }} / \mathrm{g} \mathrm{VS}_{\text {inoculum }}$ (Table 2), which could lead to overload due to VFA and/or LCFA accumulation.

Methane production is shown in Table 2. The highest methane production was obtained at $1 \% \mathrm{TS}$ and it was very similar for tuna, sardine and needle fish waste, around $0.47 \mathrm{~g} \mathrm{COD}-\mathrm{CH}_{4} / \mathrm{g} \mathrm{COD}_{\text {added }}$ $\left(0.26 \mathrm{~L} \mathrm{CH}_{4} / \mathrm{g} \mathrm{VS}_{\text {added }}\right)$. However, the production was higher with mackerel waste, reaching $0.59 \mathrm{~g}$ COD- $\mathrm{CH}_{4} / \mathrm{g} \mathrm{COD}_{\text {added }}(0.35 \mathrm{~L}$ $\mathrm{CH}_{4} / \mathrm{g} \mathrm{VS}_{\text {added }}$ ). The higher mackerel fat content (Table 1) may have influenced these results. In fact, waste lipids are ideal substrates for methane production since their degradation does theoretically

Table 1

Characterization of solid fish waste.

\begin{tabular}{lllll}
\hline & Tuna & Sardine & Mackerel & Needle \\
\hline Moisture \% & 63 & 75 & 68 & 72 \\
g VS/g dry waste & 0.796 & 0.737 & 0.851 & 0.806 \\
g COD/g dry waste & 1.392 & 1.126 & 1.423 & 1.253 \\
g TKN/g dry waste & 0.102 & 0.100 & 0.093 & 0.090 \\
g total fat/g dry waste & 0.101 & 0.068 & 0.369 & 0.162 \\
\hline
\end{tabular}
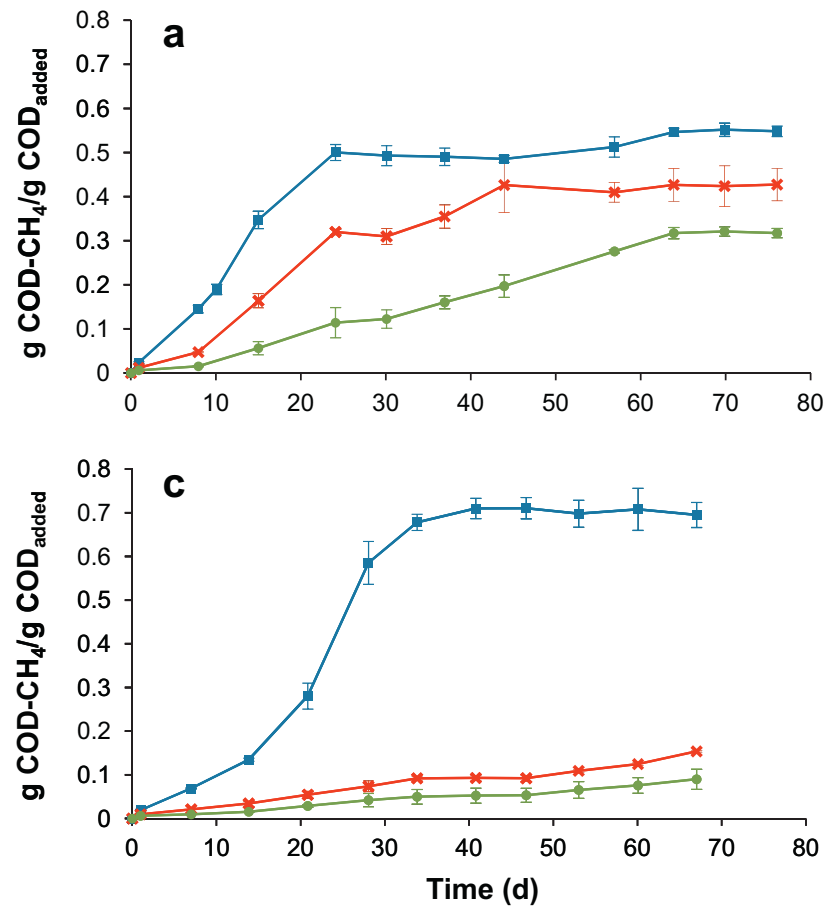

produce more biogas $(1.42 \mathrm{~L} / \mathrm{g})$ than proteins or carbohydrates (0.92 and $0.83 \mathrm{~L} / \mathrm{g}$, respectively) (Alves et al., 2009).

Mshandete et al. (2004) tested the batch anaerobic digestion of fish waste obtained from the landing beach which consisted of offal, scales, gills and washing water. As in the present study, the methane yield decreased with an increase in the total solid substrate content. The ratio of waste/inoculum was found to be a critical parameter since the methane yield increased significantly when the waste/inoculum ratio decreased from 1.6 to $0.05 \mathrm{~g}$

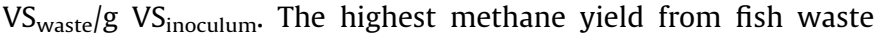
was $0.39 \mathrm{~L} \mathrm{CH}_{4} / \mathrm{g} \mathrm{VS}_{\text {added }}$ at 5\%TS. This yield is higher than the ones obtained in our study ( 0.26 and $\left.0.35 \mathrm{~L} \mathrm{CH}_{4} / \mathrm{g} \mathrm{VS}_{\text {added }}\right)$ but it was obtained at a very low waste/inoculum ratio ( 0.05 compared with 1.1-1.3 $\left.\mathrm{g} \mathrm{VS}_{\text {waste }} / \mathrm{g} \mathrm{VS}_{\text {inoculum}}\right)$. At similar waste/inoculum ratios as in our study, Mshandete and colleagues obtained methane yields below $0.1 \mathrm{~L} \mathrm{CH}_{4} / \mathrm{g} \mathrm{VS}$ added.

All fish waste presented a significant solid reduction, the solid removal was higher at $1 \% \mathrm{TS}$ and varied between 62 and $84 \%$ (Table 2 ). In spite of the inhibition of methane production in assays with 2.5 and 5\%TS, the TS and VS removal was high under such conditions. This means that the hydrolytic-acidogenic microorganisms exhibited a high activity with only a slight inhibition occurring at 2.5 and $5 \%$ TS.

During anaerobic digestion, complex organic substrates are converted basically into acids and to a lower extent into other low molecular weight compounds. The soluble chemical oxygen demand (COD) is a parameter that represents the extent of solubilization (Table 2). In all assays, the final values of CODs were higher at higher amounts of waste added, indicating that there was a percentage of solubilized COD that was not converted into methane. This percentage increased significantly at increasing total solids. The trend in the VFA concentrations increase is the same as for the CODs. VFA were not detected at 1\%TS; however, they reached high concentrations at 2.5 and 5\%TS (Table 3 ). The highest concentrations were found for acetic and propionic acids. Therefore, VFA accumulation indicates the occurrence of an imbalance between the acid-forming and the methane-forming microorganisms.
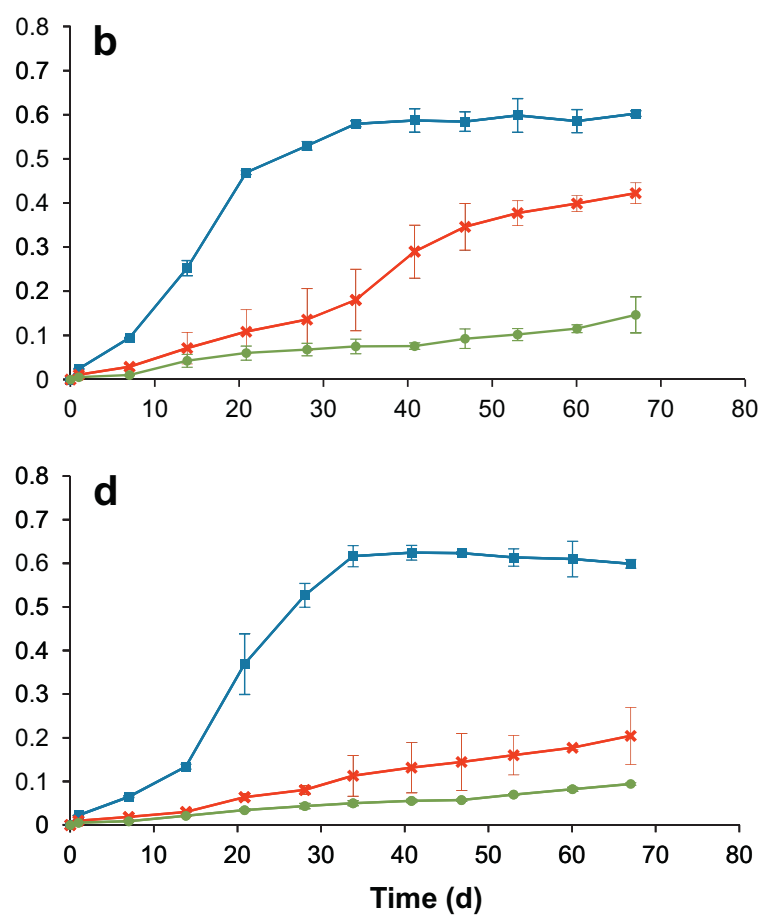

Fig. 1. Methane production regarding COD added in digestion assays of (a) tuna, (b) sardine, (c) mackerel and (d) needle fish: $1 \% \mathrm{TS}$ ( $\mathbf{\square})$, $2.5 \% \mathrm{TS}$ (x) and $5 \% \mathrm{TS}$ ( $\bullet$ ) 
Table 2

Methane production, TS and VS removal, final CODs and final ammonia in anaerobic digestion assays of solid fish waste.

\begin{tabular}{|c|c|c|c|c|c|c|c|c|}
\hline & $\% \mathrm{TS}$ & $\mathrm{VS}_{\text {waste }} / \mathrm{VS}_{\text {inoculum }}$ & g COD- $\mathrm{CH}_{4} / \mathrm{g} \mathrm{COD}_{\text {added }}$ & $\mathrm{L} \mathrm{CH}_{4} / \mathrm{g} \mathrm{VS}_{\text {added }}$ & TS removal (\%) & VS removal (\%) & Final CODs $(\mathrm{g} / \mathrm{L})$ & Final $\mathrm{N}-\mathrm{NH}_{4}{ }^{+}(\mathrm{g} / \mathrm{L})$ \\
\hline \multirow[t]{3}{*}{ Tuna } & 1 & 1.2 & 0.46 & 0.28 & 82 & 81 & 0.76 & 0.76 \\
\hline & 2.5 & 3.1 & 0.41 & 0.25 & 74 & 72 & 3.52 & 1.79 \\
\hline & 5 & 6.2 & 0.30 & 0.18 & 67 & 66 & 20.5 & 3.64 \\
\hline \multirow[t]{3}{*}{ Sardine } & 1 & 1.1 & 0.47 & 0.25 & 66 & 74 & 0.56 & 0.84 \\
\hline & 2.5 & 2.8 & 0.37 & 0.20 & 58 & 62 & 7.76 & 2.36 \\
\hline & 5 & 5.7 & 0.12 & 0.06 & 64 & 70 & 37.8 & 4.83 \\
\hline \multirow[t]{3}{*}{ Mackerel } & 1 & 1.3 & 0.59 & 0.35 & 78 & 84 & 0.63 & 0.57 \\
\hline & 2.5 & 3.3 & 0.11 & 0.07 & 45 & 49 & 16.8 & 1.69 \\
\hline & 5 & 6.5 & 0.07 & 0.04 & 44 & 49 & 32.6 & 3.22 \\
\hline \multirow[t]{3}{*}{ Needle } & 1 & 1.2 & 0.48 & 0.26 & 62 & 74 & 1.20 & 0.74 \\
\hline & 2.5 & 3.1 & 0.16 & 0.09 & 55 & 61 & 21.6 & 2.16 \\
\hline & 5 & 6.2 & 0.07 & 0.04 & 56 & 63 & 41.0 & 3.76 \\
\hline
\end{tabular}

Table 3

Final VFA concentrations ( $\mathrm{g}$ COD/L) in anaerobic digestion assays of solid fish waste.

\begin{tabular}{llclll}
\hline & \%TS & Acetic & Propionic & iso-Butyric & Valeric \\
\hline \multirow{2}{*}{ Tuna } & 2.5 & 0.67 & 0.03 & - & - \\
& 5 & 2.09 & 6.23 & - & - \\
Sardine & 2.5 & 2.86 & 1.22 & - & - \\
& 5 & 16.3 & 5.56 & 1.88 & 2.69 \\
Mackerel & 2.5 & 5.68 & 2.73 & 0.42 & 1.00 \\
& 5 & 12.9 & 4.04 & 0.84 & 3.17 \\
\multirow{2}{*}{ Needle } & 2.5 & 8.62 & 2.94 & 0.76 & 0.97 \\
& 5 & 14.0 & 4.09 & 1.53 & 1.83 \\
\hline
\end{tabular}

Raposo et al. (2009) studied the influence of the waste/inoculum ratio on the anaerobic digestion of the solid waste generated in the extraction process of sunflower oil. The VFA accumulation also increased with an increase of the waste/inoculum ratio, from 0.33

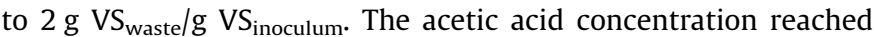
$5.9 \mathrm{~g} \mathrm{COD} / \mathrm{L}$ at $2 \mathrm{~g} \mathrm{VS}_{\text {waste }} / \mathrm{g} \mathrm{VS}_{\text {inoculum}}$, which brought methane production to an almost complete halt.

As the final VFA concentration accounted only for a percentage of the CODs, LCFA were also measured since their accumulation could have occurred due to the high lipid content of the fish waste (Table 1). Final concentrations of the most abundant LCFA in different assays are presented in Table 4. The higher the waste added the greater the accumulation of LCFA, as previously detected for CODs and VFA. The relative abundance of each type of LCFA was found to be different for the four fish waste. Stearic and oleic acids were not detected, except in assays with mackerel waste at 5\%TS, reaching 1.13 and $1.08 \mathrm{~g} \mathrm{COD} / \mathrm{L}$, respectively. As expected, mackerel presented the highest LCFA accumulation because of the lipid content (11.4 $\mathrm{g} \mathrm{COD/L}$ at 5\%TS), causing the main inhibition. Treatment of fatty materials by anaerobic digestion is often hampered because of the inhibitory effect of LCFA. In general, hydrolysis of fats and oils to glycerol and LCFA proceeds rapidly, resulting in the accumulation of LCFA in the medium (Angelidaki and Ahring, 1992). LCFA

Table 4

Final LCFA concentrations ( $\mathrm{g}$ COD/L) in anaerobic digestion assays of solid fish waste.

\begin{tabular}{llllll}
\hline & \%TS & Lauric & Myristic & Palmitic & Palmitoleic \\
\hline Tuna & 2.5 & 0.58 & - & 0.02 & 0.06 \\
& 5 & 0.54 & 0.06 & 0.03 & 0.21 \\
Sardine & 2.5 & 0.78 & - & - & 0.08 \\
& 5 & 0.95 & 0.43 & - & 2.38 \\
Mackerel & 2.5 & 0.07 & 1.62 & 4.59 & 0.09 \\
& 5 & 0.11 & 2.60 & 5.91 & 0.56 \\
Needle & 2.5 & 0.95 & 0.07 & - & 1.47 \\
& 5 & 2.95 & 1.29 & - & 5.33 \\
\hline
\end{tabular}

show acute toxicity toward anaerobic consortia by adsorption onto the cell wall/membrane, interference with the transport or protective function (Rinzema et al., 1994). In spite of inhibition, providing the appropriate technology and the right feeding strategy, LCFA can be biodegraded to methane (Alves et al., 2009).

Therefore, the CODs accumulation was mainly due to VFA and LCFA accumulation, which reflects a kinetic uncoupling between acid producing and acid consuming microorganisms, typical of a stress situation. In general, it is accepted that hydrolysis of particulate organic matter is the rate-limiting step in the anaerobic digestion of particulate substrates. However, in the present work this did not occur, since in all assays the methanation percentage (7-30\%) was lower than the solubilization percentage (53-78\%). This means that the hydrolytic-acidogenic stage was carried out satisfactorily and the imbalance of the process was due to the stress of methanogenic microorganisms.

Another factor that could have inhibited anaerobic digestion is ammonia, formed as a result of the high nitrogen concentration of the fish waste (Table 1 ). Ammonia is produced by the biological degradation of the nitrogenous matter, mostly proteins. The high nitrogen content of fish waste could be an important limiting factor for its anaerobic digestion. Results published in the literature on the inhibition caused by specific toxicants vary widely due to the difference in anaerobic inoculum, waste composition and experimental conditions. A wide range of inhibiting ammonia concentrations has been reported, with inhibitory total ammonia concentrations that caused a $50 \%$ reduction in methane production ranging from 1.7 to $14 \mathrm{~g} \mathrm{~N} / \mathrm{L}$ (Chen et al., 2008). As expected, the final ammonia concentration increased with increasing amounts of waste added, but there was no significant difference between the different fish waste (Table 2). In spite of the high ammonia concentration in assays with 2.5 and 5\%TS, it seems that this was not the only cause of inhibition since assays with a lower ammonia concentration were more inhibited than assays with a higher one. This was the case, for example, for the digestion assays at $2.5 \% \mathrm{TS}$ of mackerel versus the assays at $2.5 \% \mathrm{TS}$ of tuna.

\subsection{Influence of inoculum and waste/inoculum ratio}

In the previous assays with suspended sludge, the methane production was very low when the amount of total solids of fish waste was increased. Consequently, different approaches were attempted to enhance it, such as the use of a more active inoculum (granular sludge) and different waste/inoculum ratios. The methane production was similar at all waste/inoculum ratios $(0.8,1.3$ and $2.5 \mathrm{~g}$ $\left.\mathrm{VS}_{\text {waste }} / \mathrm{g} \mathrm{VS}_{\text {inoculum }}\right)$, around $0.47 \mathrm{~g} \mathrm{COD}-\mathrm{CH}_{4} / \mathrm{g} \mathrm{COD}$ added $(0.28 \mathrm{~L}$ $\mathrm{CH}_{4} / \mathrm{g} \mathrm{VS}_{\text {added }}$ ). However, these values are higher than the ones obtained in the previous study with the same quantity of waste and 
suspended sludge $\left(0.11 \mathrm{~g} \mathrm{COD}-\mathrm{CH}_{4} / \mathrm{g} \mathrm{COD}_{\text {added }}\right)$. The inoculum used in the batch assays can cause variations in the biodegradation rate. Granular sludge was significantly more active than suspended sludge; consequently, the methane production rate was improved. In the tested conditions, the waste/inoculum ratio did not influence the digestion assays. Neves et al. (2004) also studied the influence of the inoculum on the biomethanization of a kitchen waste at different waste/inoculum ratios. In batch assays with enough alkalinity and waste/inoculum ratios between 0.5 and $2.3 \mathrm{~g} \mathrm{VS}_{\text {waste }} / \mathrm{g}$ $\mathrm{VS}_{\text {inoculum, }}$, the use of a granular inoculum prevented acidification and the methane production was maintained. Conversely, this was not achieved in case of a suspended sludge with significantly lower activity.

TS and VS removals were also similar at all the waste/inoculum ratios and were about 59 and $51 \%$, respectively. As well, the final values of CODs were similar and around $7.2 \mathrm{~g}$ COD/L. Acetic and propionic acids were the only VFA detected, with concentrations around 0.46 and $0.12 \mathrm{~g} \mathrm{COD} / \mathrm{L}$, respectively. From the LCFA, lauric and palmitoleic acids were the ones found at the highest concentration, of about 0.54 and $0.34 \mathrm{~g}$ COD/L, respectively. The LCFA accumulation obtained with the granular sludge was lower than the one with the suspended sludge. Suspended and flocculent sludges, characterized by a higher specific surface area, suffered much more inhibition by LCFA than granular sludge (Hwu et al., 1996).

\subsection{Co-digestion of fish waste with gorse}

The co-digestion with gorse was studied in order to try to improve methane production from fish waste. The solid content and organic matter of the used gorse were $0.848 \mathrm{~g} \mathrm{VS} / \mathrm{g}$ waste and $1.161 \mathrm{~g} \mathrm{COD} / \mathrm{g}$ waste, while its nitrogen concentration was low ( $0.013 \mathrm{~g}$ TKN$/ \mathrm{g}$ waste), thereby being its composition complementary to fish waste.

Co-digestion assays of tuna waste with gorse were performed at different proportions, using granular sludge as inoculum. The cumulative methane production is shown in Fig. 2 and the methane production after correction is presented in Table 5 . The methane production was similar in all assays, around $0.36 \mathrm{~g} \mathrm{COD}-\mathrm{CH}_{4} / \mathrm{g}$ $\mathrm{COD}_{\text {added }}\left(0.20 \mathrm{~L} \mathrm{CH}_{4} / \mathrm{g} \mathrm{VS}_{\text {added }}\right)$. Therefore, the biochemical methane potential of fish waste was not improved by adding gorse. Mshandete et al. (2004) studied the anaerobic co-digestion of fish waste with sisal pulp. A methane yield of $0.31 \mathrm{~L} \mathrm{CH}_{4} / \mathrm{g} \mathrm{VS}_{\text {added }}$ was obtained with a mixture of $50 \%$ fish waste and $50 \%$ sisal pulp versus $0.39 \mathrm{~L} \mathrm{CH}_{4} / \mathrm{g} \mathrm{VS}_{\text {added }}$ with fish waste alone. Then, with this waste proportion the fish waste digestion was also not enhanced.

With regard to the solids removal, it was higher in the digestion assays containing tuna alone; while, it was lower in the ones containing gorse alone (Table 5). The gorse is a substrate more com-

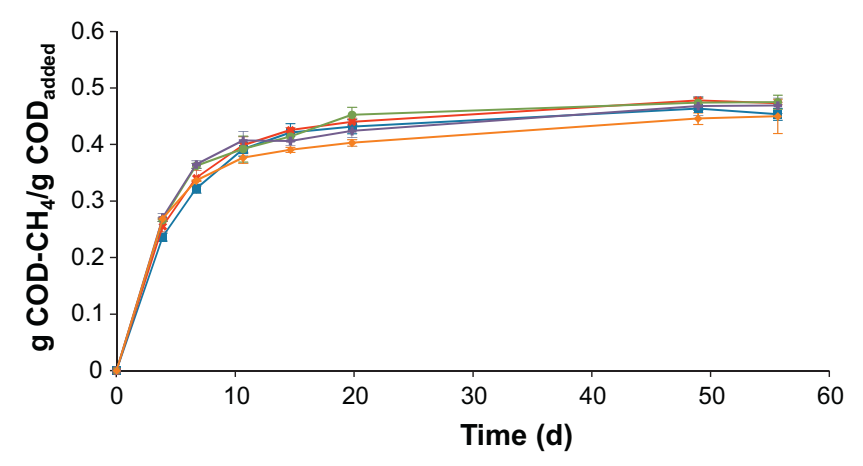

Fig. 2. Methane production regarding COD added in co-digestion assays of different

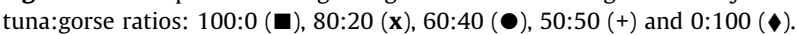

Table 5

Methane production, TS and VS removal, final CODs and final ammonia in anaerobic co-digestion assays of tuna waste with gorse.

\begin{tabular}{|c|c|c|c|c|c|c|}
\hline Tuna:gorse & $\begin{array}{l}\text { g COD- } \\
\mathrm{CH}_{4} / \mathrm{g} \\
\mathrm{COD}_{\text {added }}\end{array}$ & $\begin{array}{l}\mathrm{L} \mathrm{CH}_{4} / \\
\mathrm{g} \\
\mathrm{VS}_{\text {added }}\end{array}$ & $\begin{array}{l}\text { TS } \\
\text { removal } \\
(\%)\end{array}$ & $\begin{array}{l}\text { VS } \\
\text { removal } \\
(\%)\end{array}$ & $\begin{array}{l}\text { Final } \\
\text { CODs } \\
(\mathrm{g} / \mathrm{L})\end{array}$ & $\begin{array}{l}\text { Final N- } \\
\mathrm{NH}_{4}^{+} \\
(\mathrm{g} / \mathrm{L})\end{array}$ \\
\hline 100:0 & 0.35 & 0.21 & 69 & 74 & 5.41 & 1.95 \\
\hline $80: 20$ & 0.37 & 0.21 & 53 & 56 & 2.08 & 1.45 \\
\hline $60: 40$ & 0.37 & 0.20 & 44 & 44 & 1.48 & 1.37 \\
\hline $50: 50$ & 0.36 & 0.20 & 51 & 53 & 1.22 & 0.97 \\
\hline $0: 100$ & 0.34 & 0.16 & 34 & 38 & 0.16 & 0.33 \\
\hline
\end{tabular}

plex to biodegrade, since the hydrolysis of lignocellulosic material is difficult without pre-treatments. As in the previous study with suspended sludge, the higher final CODs obtained at higher quantities of tuna added show a kinetic uncoupling between hydrolytic-acidogenic microorganisms and methanogenic microorganisms. In digestion assays containing gorse alone, VFA were not detected. The final VFA and LCFA concentrations increased for increasing amounts of tuna. This is in agreement with the lipid content of the tuna waste. In assays containing tuna alone, the VFA and LCFA values reached 2.05 and $1.19 \mathrm{~g}$ COD/L, respectively. As expected, the ammonia concentration also increased with an increase in the amount of tuna added (Table 5), since ammonia is produced by the biological degradation of the nitrogenous matter, which is very low in the gorse used in this study.

\section{Conclusions}

The biochemical methane potential of different solid fish waste was studied. The highest methane production was obtained at $1 \% \mathrm{TS}$ of waste. It was very similar for tuna, sardine and needle fish waste, around $0.47 \mathrm{~g} \mathrm{COD}-\mathrm{CH}_{4} / \mathrm{g} \mathrm{COD}$ added. However, the production was higher with mackerel waste, reaching $0.59 \mathrm{~g} \mathrm{COD}-\mathrm{CH}_{4} / \mathrm{g}$ $\mathrm{COD}_{\text {added }}$, likely due to the higher fat content.

The increase in the waste/inoculum ratio led to overload due to VFA and LCFA accumulation. These results reflect a kinetic uncoupling between acid producing and acid consuming microorganisms which is typical of a process imbalance. Granular sludge was significantly more active than suspended sludge; consequently, the methane production rate was higher using granular sludge.

Methane production was similar in co-digestion of fish waste with gorse at different proportions, around $0.36 \mathrm{~g} \mathrm{COD}-\mathrm{CH}_{4} / \mathrm{g}$ $\mathrm{COD}_{\text {added. }}$ Therefore, the biochemical methane potential of fish waste was not improved by adding gorse.

Further research is needed in co-digestion with other waste able to establish positive synergism in the digestion medium. The adaptation of the inoculum could also be an important factor in order to enhance the treatment efficiency. It is planned to run a continuous stirred tank reactor with fish waste in order to try to avoid VFA and LCFA accumulation and to improve methane production.

\section{Acknowledgements}

This work was supported by project QREN SI-I\&DT, number 2509 from 15/5/2008. Marta Eiroa wishes to express her gratitude to the "Xunta de Galicia" (Spain) for her post-doc fellowship (Ángeles Alvariño) and José Carlos Costa to the "Fundação para a Ciência e a Tecnologia" (Portugal) and "Fundo Social Europeu" through the Grant SFRH/BDP/48962/2008. The authors thank the Ministry of Science and Innovation of the Spanish government for the funds provided through the Torres Quevedo Programme (PTQ-09-0201663) and the collaboration with Bilega Energía S.L. 


\section{References}

Alves, M.M., Pereira, M.A., Sousa, D.Z., Cavaleiro, A.J., Picavet, M., Smidt, H., Stams, A.J.M., 2009. Waste lipids to energy: how to optimize methane production from long-chain fatty acids (LCFA) (Minireview). Microbial Biotechnology 2 (5), 538 550 .

Angelidaki, I., Ahring, B.K., 1992. Effects of free long-chain fatty acids on thermophilic anaerobic digestion. Applied Microbiology and Biotechnology $37,808-812$.

Angelidaki, I., Alves, M.M., Bolzonella, D., Borzacconi, L., Campos, J.L., Guwy, A.J., Kalyuzhnyi, S., Jenicek, P., van Lier, J.B., 2009. Defining the biomethane potential (BMP) of solid organic waste and energy crops: a proposed protocol for batch assays. Water Science and Technology 59 (5), 927-934.

APHA, AWWA, WEF, 1998. Standard Methods for the Examination of Water and Wastewater, 20th ed. Washington DC, USA.

Bouallagui, H., Lahdheb, H., Ben Romdan, E., Rachdi, B., Hamdi, M., 2009. Improvement of fruit and vegetable waste anaerobic digestion performance and stability with co-substrates addition. Journal of Environmental Management 90, 1844-1849.

Callaghan, F.J., Wase, D.A.J., Thayanithy, K., Forster, C.F., 1999. Co-digestion of waste organic solids: batch studies. Bioresource Technology 67, 117-122.

Chen, Y., Cheng, J.J., Creamer, K.S., 2008. Inhibition of anaerobic digestion process: a review. Bioresource Technology 99, 4044-4064.

De Baere, L., Mattheeuws, B., 2010. Anaerobic digestion of MSW in Europe. Biocycle $51(2), 24$.
Hwu, C.S., Donlon, B., Lettinga, G., 1996. Comparative toxicity of long-chain fatty acids to anaerobic sludges from various origins. Water Science and Technology 34 (5-6), 351-358.

Mata-Alvarez, J., Macé, S., Llabrés, P., 2000. Anaerobic digestion of organic solid wastes. An overview of research achievements and perspectives (Review paper). Bioresource Technology 75, 3-16.

Mshandete, A., Kivaisi, A., Rubindamayugi, M., Mattiasson, B., 2004. Anaerobic batch co-digestion of sisal pulp and fish wastes. Bioresource Technology 95 19-24.

Neves, L., Oliveira, R., Alves, M.M., 2004. Influence of inoculum activity on the biomethanization of a kitchen waste under different waste/inoculum ratios. Process Biochemistry 39, 2019-2024.

Neves, L., Pereira, M.A., Mota, M., Alves, M.M., 2009. Detection and quantification of long chain fatty acids in liquid and solid samples and its relevance to understand anaerobic digestion of lipids. Bioresource Technology 100, 91-96.

Núñez-Regueira, L., Rodríguez-Añón, J., Proupín, J., Vilanova, Diz.A., 2002 Calorimetry as a tool to design campaigns to prevent and fight forest fires originating from shrub species. Thermochimica Acta 394, 279-289.

Raposo, F. Borja, R., Martín, M.A., Martín, A. de la Rubia, M.A., Rincón, B. 2009. Influence of inoculum-substrate ratio on the anaerobic digestion of sunflower oil cake in batch mode: process stability and kinetic evaluation. Chemica Engineering Journal 149, 70-77.

Rinzema, A., Boone, M., van Knippenberg, K., Lettinga, G., 1994. Bacterial effect of long chain fatty acids in anaerobic digestion. Water Environmental Research 66 $40-49$. 